Article

\title{
Dolomite-Derived Ni-Based Catalysts with Fe Modification for Hydrogen Production via Auto-Thermal Reforming of Acetic Acid
}

\author{
Xinyan Zhong ${ }^{1}$, Wei Xie ${ }^{1}$, Ning Wang ${ }^{2}$, Yiping Duan ${ }^{1}$, Ruishu Shang ${ }^{1}$ and Lihong Huang ${ }^{1,3, *}$ \\ 1 Department of Chemical and Pharmaceutical Engineering, Chengdu University of Technology, \\ Chengdu 610059, China; xinyan_zhong@yahoo.com (X.Z.); xiewei0403@yahoo.com (W.X.); \\ duanyipingyznu@yahoo.com (Y.D.); shangruishu@yahoo.com (R.S.) \\ 2 Department of Chemical Engineering, Tsinghua University, Beijing 100084, China; \\ maibucongtouyue@163.com \\ 3 Richard G. Lugar Center for Renewable Energy, Indiana University-Purdue University, Indianapolis, \\ IN 46224, USA \\ * Correspondence: huanglihong06@cdut.cn or lihhuang@iupui.edu; Tel.: +86-28-8407-8939; \\ Fax: +86-28-8407-9074
}

Academic Editor: Ivan V. Kozhevnikov

Received: 18 May 2016; Accepted: 8 June 2016; Published: 15 June 2016

\begin{abstract}
Bio-oil can be obtained via fast pyrolysis of biomass, and typically contains acetic acid ( 30 mass \%). The acetic acid has often been tested as a model compound for hydrogen production via reforming bio-oil, in which catalysts are a key factor for stable hydrogen production. However, deactivation of catalysts by coking and oxidation hinders the application of the reforming process. Dolomite-derived Ni-based catalysts with Fe additive, $\mathrm{MgNi}_{0.2} \mathrm{Ca}_{0.8}{ }_{-x} \mathrm{Fe}_{x} \mathrm{O}_{2 \pm \delta}(x=0-0.8)$, were successfully synthesized by the hydrothermal synthesis method, and then tested in auto-thermal reforming (ATR) of acetic acid (AC). The $\mathrm{MgNi}_{0.2} \mathrm{Ca}_{0.5} \mathrm{Fe}_{0.3} \mathrm{O}_{2 \pm \delta}$ catalyst performed a stable reactivity in ATR: the conversion of $\mathrm{AC}$ reached $100 \%$, and the $\mathrm{H}_{2}$ yield remained stable around 2.6 mol- $\mathrm{H}_{2} /$ mol-AC. The catalysts were characterized by $\mathrm{X}$-ray diffraction (XRD), $\mathrm{N}_{2}$ physisorption, $\mathrm{X}$-ray photoelectron spectra (XPS), $\mathrm{H}_{2}$-temperature-programmed reduction (TPR), inductively coupled plasma- atomic emission spectroscopy (ICP-AES) and Thermogravimetry (TG); the results show that a periclase-like solid solution of $\mathrm{Mg}(\mathrm{Ni}, \mathrm{Fe}) \mathrm{O}$ and lime were formed via the precursors of dolomite and hydrotalcite, and then transformed into Fe-rich Ni-Fe alloy with basic support of $\mathrm{MgO}-\mathrm{CaO}$ after reduction. The stable $\mathrm{Ni}^{0}$ spices with basic support can explain the stability and resistance to coking during ATR of AC.
\end{abstract}

Keywords: dolomite-derived Ni-based catalyst; auto-thermal reforming of acetic acid; hydrothermal synthesis; Ni-Fe alloy; bio-oil

\section{Introduction}

Hydrogen has long been viewed as a clean energy carrier, and can be extracted via reforming of fossil resources, e.g., natural gas or coal. Biomass is an important alternative renewable $\mathrm{CO}_{2}$-neutral resource for hydrogen production, while bio-oil produced via fast-pyrolysis of biomass is attracting attention for its high energy density and transportation convenience [1-3]. Within bio-oil, acetic acid (AC) is one of the major components ( $\sim 30$ mass \%), and has often been tested as a model compound for hydrogen production via processes of steam reforming $\left(\mathrm{SR}, \mathrm{CH}_{3} \mathrm{COOH}+2 \mathrm{H}_{2} \mathrm{O} \rightarrow\right.$ $\left.2 \mathrm{CO}_{2}+4 \mathrm{H}_{2}-131.4 \mathrm{~kJ} / \mathrm{mol}\right)[2,4,5]$.

$\mathrm{SR}$ is a strong endothermic process and requires an external heat sources [1,6], while auto-thermal reforming (ATR) with endothermic steaming reforming (SR) and exothermic partial oxidation reaction 
(POX) can be a solution for heat balance via adjusting the feed proportions of oxygen, acetic acid (AC), and steam, e.g., $\mathrm{CH}_{3} \mathrm{COOH}+1.44 \mathrm{H}_{2} \mathrm{O}+0.28 \mathrm{O}_{2} \rightarrow 2 \mathrm{CO}_{2}+3.44 \mathrm{H}_{2}[1,7]$.

However, coke deposition can be a concern. For example, Ni-based catalysts have been widely investigated due to its high catalytic activity for breakage of $\mathrm{C}-\mathrm{C}$ in the reforming process; on the other hand, acidic sites within the supports of $\mathrm{Al}_{2} \mathrm{O}_{3}$ or $\mathrm{ZrO}_{2}$ favor decomposition and polymerization of $\mathrm{AC}$ with derivatives of acetone, ethylene, etc., resulting in carbon deposition $[4,8]$. Therefore, oxides of alkaline earth metals with basic sites, e.g., $\mathrm{MgO}$ and $\mathrm{CaO}$, have been used as supports or additives and proved effective to suppress coking over acidic sites [9-11].

There are other issues within ATR as well: because of the oxidative atmosphere and high temperature (up to $1000{ }^{\circ} \mathrm{C}$ ) in the upstream zone of the fixed-bed reactor for ATR, oxidation and sintering of metallic Ni occurred and resulted in catalyst deactivation [1,12].

Dolomite, or calcium magnesium carbonate with well-dispersed species of calcium, magnesium, and nickel, can be a promising candidate for ATR of AC. Within dolomite-derived Ni-based catalysts, alkaline earth oxides of $\mathrm{CaO}$ and $\mathrm{MgO}$ with Lewis basic sites could promote adsorption and migration of $\mathrm{H}_{2} \mathrm{O}$ and $\mathrm{OH}$ groups over the catalyst's surface, and promote carbon gasification and reduce carbon deposition $[9,10,13]$. Meanwhile, $\mathrm{Ca}$ or $\mathrm{Mg}$ can be partly replaced by active component of $\mathrm{Ni}$ in a form of solid solution, e.g., $\mathrm{Ni}$ inserted in the skeleton of periclase as $\mathrm{Mg}(\mathrm{Ni}) \mathrm{O}$ to improve dispersion and thermal stability [12]. For the issue of Ni oxidation, additive of Fe was proved effective to resist oxidation of Ni species [12,14]. Regarding the preparation method of catalysts, a synthesis strategy, e.g., hydrothermal synthesis, has long been used to synthesize catalysts with high porosity and dispersion of active components [15,16].

In the present work, precursors with a dolomite structure were fabricated via hydrothermal synthesis, and calcium was partly replaced by an active component of nickel and an additive of iron. These dolomite-derived catalysts $\left(\mathrm{MgNi}_{0.2} \mathrm{Ca}_{0.8-} \mathrm{Fe}_{x} \mathrm{O}_{2 \pm \delta}(x=0-0.8)\right)$ were then tested in ATR of AC for hydrogen production, and characterizations of X-ray diffraction (XRD), X-ray photoelectron spectra (XPS), TPR, etc. were conducted to study the relationship between structure and reactivity. To the best of the authors' knowledge, these dolomite-derived $\mathrm{MgNi}_{0.2} \mathrm{Ca}_{0.8-} \mathrm{Fe}_{x} \mathrm{O}_{2 \pm \delta}$ catalysts have not been reported for ATR of AC for hydrogen production, and are listed in Table 1.

Table 1. The list of Ni-based dolomite-derived catalysts with Fe promotion as prepared.

\begin{tabular}{|c|c|c|c|c|c|c|c|}
\hline \multirow{2}{*}{ Catalysts } & \multirow{2}{*}{$\begin{array}{l}\text { Nominal Molar } \\
\text { Composition }\end{array}$} & \multicolumn{4}{|c|}{ Weight Compositions Analyzed by ICP-AES/\% } & \multirow{2}{*}{$\begin{array}{c}\text { Surface } \\
\text { Area } /\left(\mathrm{m}^{2} / \mathrm{g}\right)\end{array}$} & \multirow{2}{*}{$\begin{array}{c}\text { Average Pore } \\
\text { Size/nm }\end{array}$} \\
\hline & & $\mathrm{MgO}$ & $\mathrm{NiO}$ & $\mathrm{CaO}$ & $\mathrm{Fe}_{2} \mathrm{O}_{3}$ & & \\
\hline $\mathrm{MNC}_{0.8} \mathrm{~F}_{0.0}$ & $\mathrm{MgNi}_{0.2} \mathrm{Ca}_{0.8} \mathrm{O}_{2 \pm \delta}$ & 39.12 & 15.11 & 45.77 & 0.00 & 4.27 & 7.44 \\
\hline $\mathrm{MNC}_{0.7} \mathrm{~F}_{0.1}$ & $\mathrm{MgNi}_{0.2} \mathrm{Ca}_{0.7} \mathrm{Fe}_{0.1} \mathrm{O}_{2 \pm \delta}$ & 38.42 & 14.40 & 39.67 & 7.51 & 6.62 & 6.52 \\
\hline $\mathrm{MNC}_{0.5} \mathrm{~F}_{0.3}$ & $\mathrm{MgNi}_{0.2} \mathrm{Ca}_{0.5} \mathrm{Fe}_{0.3} \mathrm{O}_{2 \pm \delta}$ & 37.74 & 13.91 & 26.33 & 22.02 & 8.71 & 6.16 \\
\hline $\mathrm{MNC}_{0.3} \mathrm{~F}_{0.5}$ & $\mathrm{MgNi}_{0.2} \mathrm{Ca}_{0.3} \mathrm{Fe}_{0.5} \mathrm{O}_{2 \pm \delta}$ & 34.84 & 13.29 & 16.68 & 35.19 & 11.53 & 5.87 \\
\hline $\mathrm{MNC}_{0.0} \mathrm{~F}_{0.8}$ & $\mathrm{MgNi}_{0.2} \mathrm{Fe}_{0.8} \mathrm{O}_{2 \pm \delta}$ & 33.01 & 12.31 & 0.00 & 54.68 & 4.69 & 5.37 \\
\hline
\end{tabular}

\section{Results}

\subsection{Auto-Thermal Reforming of Acetic Acid}

ATR of acetic acid (AC), $\mathrm{CH}_{3} \mathrm{COOH}+1.44 \mathrm{H}_{2} \mathrm{O}+0.28 \mathrm{O}_{2} \rightarrow 2 \mathrm{CO}_{2}+3.44 \mathrm{H}_{2}$, was conducted over the Ni-based dolomite-derived catalysts at conditions of $650{ }^{\circ} \mathrm{C}, 3.6 \mathrm{~g}-\mathrm{AC} /(\mathrm{g}$-catalyst.h) and $1 \mathrm{~atm}$ for $10 \mathrm{~h}$. For the iron-free catalyst of $\mathrm{MNC}_{0.8} \mathrm{~F}_{0.0}$ (Figure 1a), the $\mathrm{AC}$ conversion started near $99.0 \%$ and decreased slightly to $97.2 \%$ in the end, while the $\mathrm{H}_{2}$ yield was recorded near $2.1 \mathrm{~mol}-\mathrm{H}_{2} / \mathrm{mol}-\mathrm{AC}$. 1 mol- $\mathrm{H}_{2} / \mathrm{mol}-\mathrm{AC}$, as indicated in Table 2 of the average activity data during the ATR process. For the carbon-containing products, the selectivity to $\mathrm{CO}_{2}$ and $\mathrm{CO}$ remained stable near $67.1 \%$ and $18.7 \%$, respectively, and the selectivity to $\mathrm{CH}_{4}$ was recorded near 3.3\%. In the meantime, the selectivity to acetone varied near $10.4 \%$, suggesting that part of acetic acid was transformed into acetone via the ketonization route $\left(2 \mathrm{CH}_{3} \mathrm{COOH} \rightarrow \mathrm{CH}_{3} \mathrm{COCH}_{3}+\mathrm{CO}_{2}+\mathrm{H}_{2} \mathrm{O}\right)$ and the produced acetone has not been converted via reaction of steam reforming $\left(\mathrm{CH}_{3} \mathrm{COCH}_{3}+5 \mathrm{H}_{2} \mathrm{O} \rightarrow 3 \mathrm{CO}_{2}+8 \mathrm{H}_{2}\right)[17,18]$. 


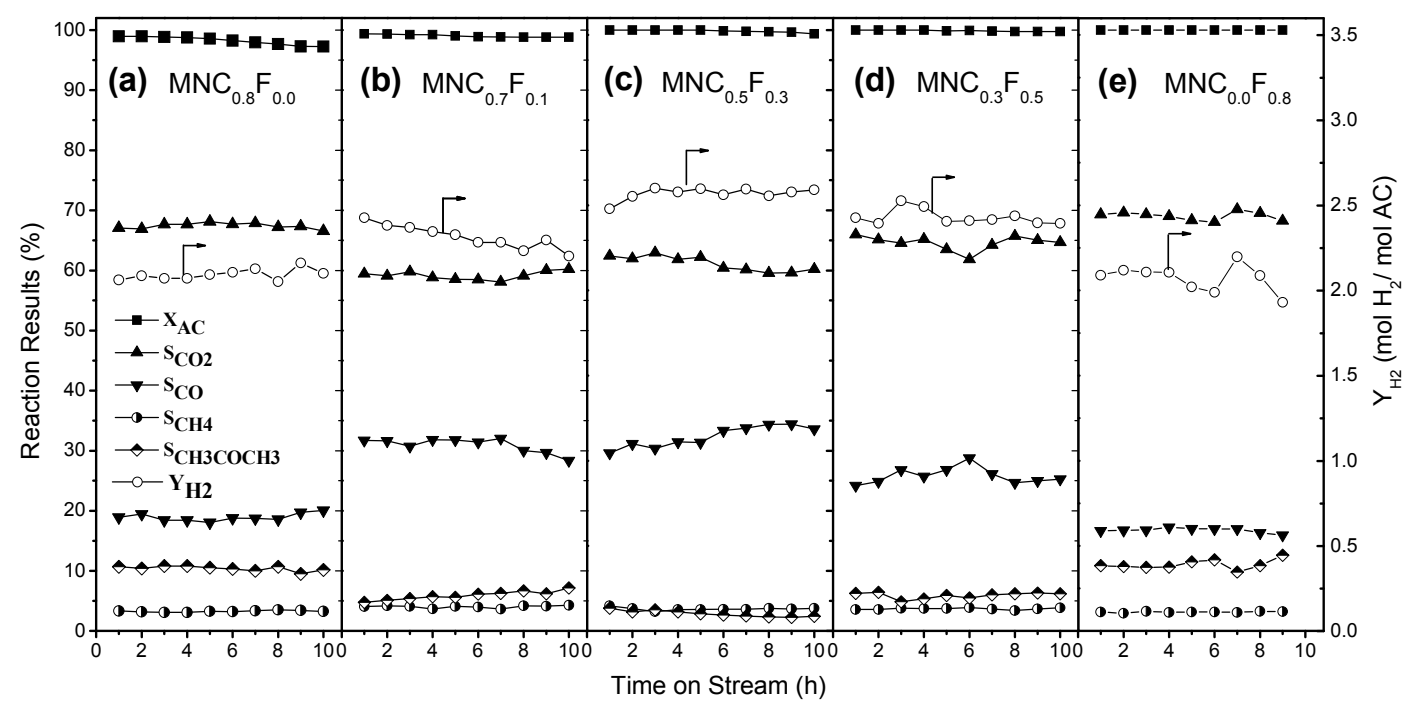

Figure 1. Auto-thermal reforming (ATR) of acetic acid (AC) over Ni-based catalysts at $650{ }^{\circ} \mathrm{C}$, 3.6 g-AC/(g-catalyst.h) and 1 atm. (a) $\mathrm{MNC}_{0.8} \mathrm{~F}_{0.0} ;$ (b) $\mathrm{MNC}_{0.7} \mathrm{O}_{0.1} ;$ (c) $\mathrm{MNC}_{0.5} \mathrm{~F}_{0.3} ;$ (d) $\mathrm{MNC}_{0.3} \mathrm{~F}_{0.5}$; (e) $\mathrm{MNC}_{0.0} \mathrm{~F}_{0.8}$.

Table 2. The average data of ATR of acetic acid over Ni-based catalysts at $650^{\circ} \mathrm{C}, 3.6 \mathrm{~g}-\mathrm{AC} /(\mathrm{g}$-catalyst.h) and $1 \mathrm{~atm}$.

\begin{tabular}{ccccccc}
\hline Catalysts & $\mathbf{X}_{\mathbf{A C}}$ & $\mathbf{S}_{\mathbf{C O}}$ & $\mathbf{S}_{\mathbf{C O}_{2}}$ & $\mathbf{S}_{\mathbf{C H}_{4}}$ & $\mathbf{S}_{\mathbf{C H}_{3} \mathbf{C O C H}_{3}}$ & $\mathbf{Y}_{\mathbf{H}_{2}}$ \\
\hline $\mathrm{MNC}_{0.8} \mathrm{~F}_{0.0}$ & 98.2 & 67.4 & 18.9 & 3.3 & 10.4 & 2.09 \\
$\mathrm{MNC}_{0.7} \mathrm{~F}_{0.1}$ & 99.0 & 59.1 & 30.9 & 4.0 & 5.9 & 2.31 \\
$\mathrm{MNC}_{0.5} \mathrm{~F}_{0.3}$ & 99.9 & 61.1 & 32.3 & 3.7 & 2.9 & 2.59 \\
$\mathrm{MNC}_{0.3} \mathrm{~F}_{0.5}$ & 99.9 & 64.6 & 25.8 & 3.7 & 5.9 & 2.43 \\
$\mathrm{MNC}_{0.0} \mathrm{~F}_{0.8}$ & 100.0 & 69.1 & 16.7 & 3.2 & 11.0 & 2.07 \\
\hline
\end{tabular}

With calcium partially replaced by iron in $\mathrm{MNC}_{0.7} \mathrm{~F}_{0.1}$ (Figure $1 \mathrm{~b}$ ), the conversion of $\mathrm{AC}$ reached 99.3\% in the beginning and remained stable, while the $\mathrm{H}_{2}$ yield was improved and varied within 2.21-2.43 mol- $\mathrm{H}_{2} / \mathrm{mol}-\mathrm{AC}$. The improvement of $\mathrm{H}_{2}$ yield can be attributed to decrease of the selectivity to acetone near $5.90 \%$, suggesting that the ketonization route was constrained. Meanwhile, the selectivity to $\mathrm{CO}_{2}$ and $\mathrm{CO}$ remained near $59.2 \%$ and $30.9 \%$, respectively.

For $\mathrm{MNC}_{0.5} \mathrm{~F}_{0.3}$ in Figure 1c, a better performance of activity and stability was observed: the AC disappeared in the product gas, and the $\mathrm{H}_{2}$ yield reached $2.6 \mathrm{~mol}-\mathrm{H}_{2} / \mathrm{mol}-\mathrm{AC}$ and remained stable during the 10-h ATR test. In the meantime, the selectivity to acetone decreased to $2.9 \%$ over time; on the other hand, the selectivity to $\mathrm{CO}_{2}$ and $\mathrm{CO}$ varied near $61.1 \%$ and $32.3 \%$, respectively; the selectivity to $\mathrm{CH}_{4}$ remained stable around $3.7 \%$. The reactivity of $\mathrm{MNC}_{0.5} \mathrm{~F}_{0.3}$ was similar to an olivine-derived catalyst of $\mathrm{Mg}_{1.7} \mathrm{Ni}_{0.3} \mathrm{SiO}_{4}$, which was tested at a much higher temperature of $800{ }^{\circ} \mathrm{C}$ and hydrogen yield was recorded near 2.73-3.06 mol- $\mathrm{H}_{2} / \mathrm{mol}-\mathrm{AC}$ [7]. Another Ni-Co bi-metal catalyst of $\left(\mathrm{Ni}_{0.2} \mathrm{Co}_{0.8} \mathrm{Mg}_{6} \mathrm{O}_{7 \pm \delta}\right)$ was tested in endothermic process of steam reforming (SR) of AC, instead of ATR, and a hydrogen yield of 2.6-3.1 mol- $\mathrm{H}_{2} / \mathrm{mol}-\mathrm{AC}$ was obtained at $600{ }^{\circ} \mathrm{C}$ [19].

With the increasing iron in $\mathrm{MNC}_{0.3} \mathrm{~F}_{0.5}$ (Figure 1d), the $\mathrm{H}_{2}$ yield dropped slightly to about 2.4 mol- $\mathrm{H}_{2} / \mathrm{mol}-\mathrm{AC}$, and the conversion of $\mathrm{AC}$ reached $100 \%$, while the selectivity to acetone increased slightly to $5.9 \%$.

Over the Ca-free catalyst of $\mathrm{MNC}_{0.0} \mathrm{~F}_{0.8}$ (Figure 1e), the $\mathrm{H}_{2}$ yield decreased to $2.1 \mathrm{~mol}-\mathrm{H}_{2} /$ mol-AC. This lower $\mathrm{H}_{2}$ yield can be attributed to a higher selectivity to acetone, which reached $12.6 \%$ in the end.

The $\mathrm{MNC}_{0.5} \mathrm{~F}_{0.3}$ catalyst produced a stable $\mathrm{H}_{2}$ yield at $650{ }^{\circ} \mathrm{C}$, and was further tested from $500{ }^{\circ} \mathrm{C}$ to $800{ }^{\circ} \mathrm{C}$ to analyze the effect of temperatures. As shown in Figure $2 \mathrm{a}$, over the $\mathrm{MNC}_{0.5} \mathrm{~F}_{0.3}$ catalyst, the conversion of $\mathrm{AC}$ started near $97.9 \%$ at $500{ }^{\circ} \mathrm{C}$, and reached $100 \%$ as the temperature increased 
to $550{ }^{\circ} \mathrm{C}$ or higher. In the meantime, the $\mathrm{H}_{2}$ yield was obtained at $1.38 \mathrm{~mol}-\mathrm{H}_{2} / \mathrm{mol}-\mathrm{AC}$ at $500{ }^{\circ} \mathrm{C}$, and this low yield can be attributed to high selectivity to the byproduct of acetone near $15.06 \%$. With increasing temperatures, the selectivity to acetone decreased continuously and disappeared at $700{ }^{\circ} \mathrm{C}$. As a result, the $\mathrm{H}_{2}$ yield increased and reached $2.89 \mathrm{~mol}-\mathrm{H}_{2} / \mathrm{mol}-\mathrm{AC}$. With higher temperatures up to $800{ }^{\circ} \mathrm{C}$, the $\mathrm{H}_{2}$ yield dropped to about 2.65 mol- $\mathrm{H}_{2} /$ mol-AC because the selectivity to methane increased to $10.85 \%$ via thermal decomposition of acetic acid $\left(\mathrm{CH}_{3} \mathrm{COOH} \rightarrow \mathrm{CH}_{4}+\mathrm{CO}_{2}\right)$.
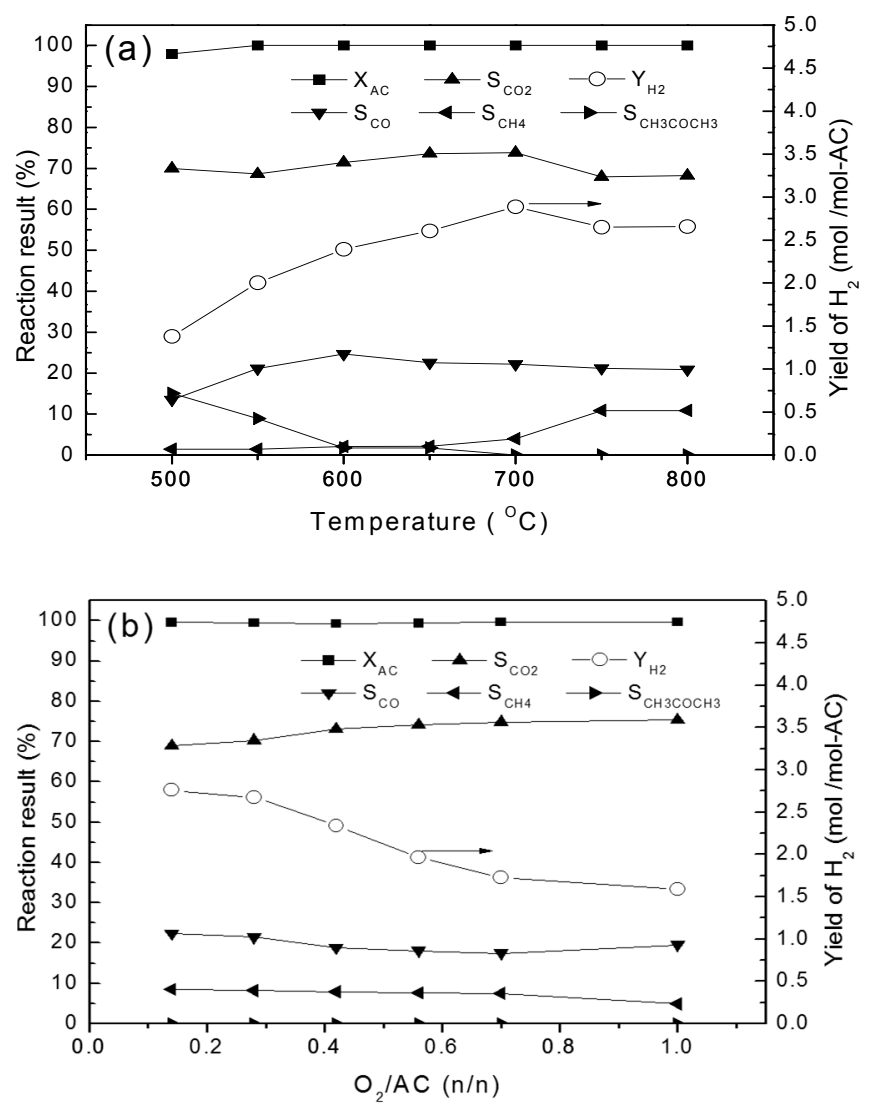

Figure 2. (a) Effect of temperature on the catalytic performance of $\mathrm{MNC}_{0.5} \mathrm{~F}_{0.3}$ in ATR of $\mathrm{AC}$ at $3.6 \mathrm{~g}-\mathrm{AC} /\left(\mathrm{g}\right.$-catalyst.h) and $1 \mathrm{~atm}$; (b) effect of $\mathrm{O}_{2} / \mathrm{AC}$ on the catalytic performance of $\mathrm{MNC}_{0.5} \mathrm{~F}_{0.3}$ in ATR at $3.6 \mathrm{~g}-\mathrm{AC} /\left(\mathrm{g}\right.$-catalyst.h), $1 \mathrm{~atm}$ and $650^{\circ} \mathrm{C}$.

The effect of $\mathrm{O}_{2} / \mathrm{AC}$ in feed was tested as well. As shown in Figure 2b, with different ratio of $\mathrm{O}_{2}$ / AC up to 1.0, the conversion of AC remained stable near $100 \%$, while the $\mathrm{H}_{2}$ yield was recorded near 2.79 mol- $\mathrm{H}_{2} /$ mol-AC at $\mathrm{O}_{2} / \mathrm{AC}=0.14$; with higher $\mathrm{O}_{2} / \mathrm{AC}$, the $\mathrm{H}_{2}$ yield dropped slightly to $2.67 \mathrm{~mol}-\mathrm{H}_{2} / \mathrm{mol}-\mathrm{AC}$ at $\mathrm{O}_{2} / \mathrm{AC}=0.28$ and further to 1.59 mol- $\mathrm{H}_{2} / \mathrm{mol}-\mathrm{AC}$ when $\mathrm{O}_{2} / \mathrm{AC}$ reached 1.0. Meanwhile, the selectivity to $\mathrm{CO}_{2}$ increased with higher ratio of $\mathrm{O}_{2} / \mathrm{AC}$. The selectivity to $\mathrm{CH}_{4}$ decreased, suggesting that $\mathrm{O}_{2}$ in ATR of AC was helpful to convert $\mathrm{CH}_{4}$. Considering the heat balance in ATR, the ratio of $\mathrm{O}_{2} / \mathrm{AC}$ near 0.28 can be adopted with heat balance and high catalytic performance.

\subsection{Characterizations}

\subsubsection{Precursors of Catalysts}

To find the structure variation of these Ni-based catalysts with Ca replaced by $\mathrm{Fe}$, the precursors were firstly characterized by X-ray diffraction (XRD). For the iron-free catalyst of $\mathrm{MNC}_{0.8} \mathrm{~F}_{0.0}$ $\left(\mathrm{MgNi}_{0.2} \mathrm{Ca}_{0.8} \mathrm{O}_{2 \pm \delta}\right)$ in Figure $3 \mathrm{a}(1)$, strong peaks at $30.9^{\circ}, 37.4^{\circ}, 41.1^{\circ}, 50.5^{\circ}$, and $51.0^{\circ}$ indicate that a main structure of dolomite $\left(\mathrm{CaMg}\left(\mathrm{CO}_{3}\right)_{2}\right.$, JCPDS: 36-0426) was successfully synthesized. Meanwhile, 
the brucite structure $\left(\mathrm{Mg}(\mathrm{OH})_{2}\right.$, JCPDS: 86-0441) with a similar structure of $\mathrm{Ni}(\mathrm{OH})_{2}$ (JCPDS: 14-0117) were observed, and traces of calcite ( $\mathrm{CaCO}_{3}$, JCPDS: 05-0586) can be found as well.

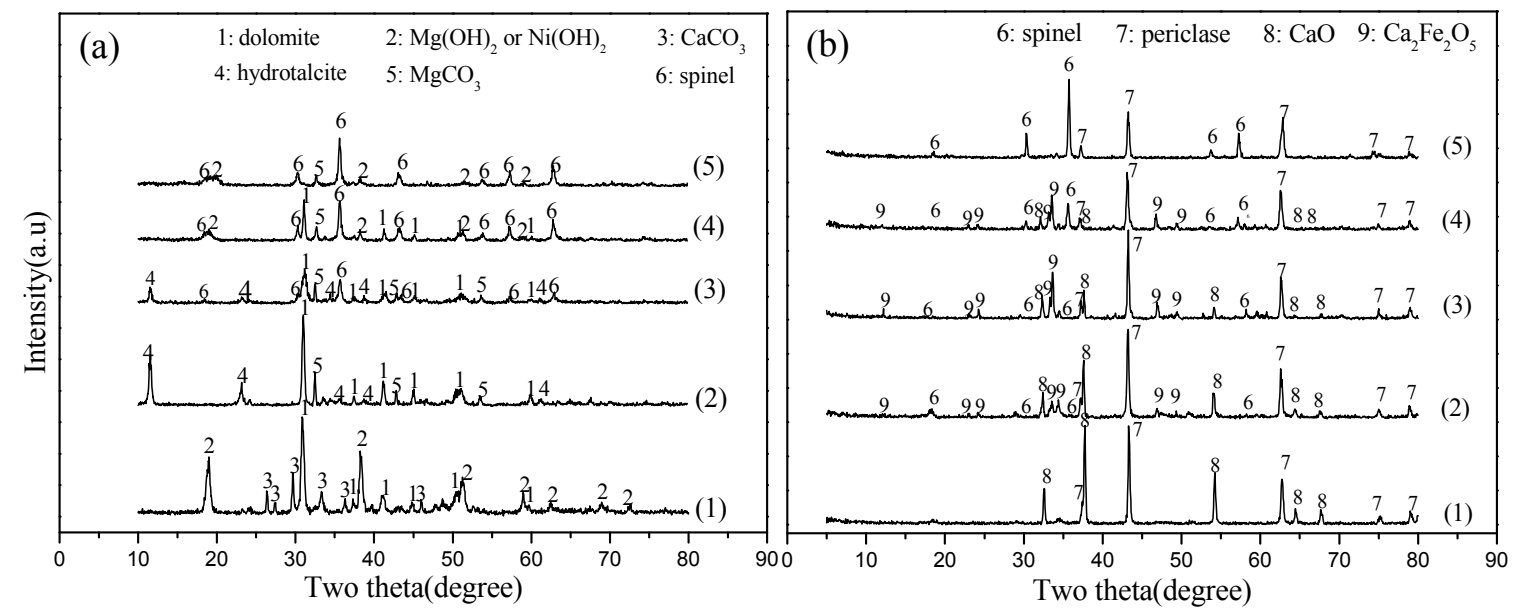

Figure 3. X-ray diffraction (XRD) patterns of Ni-based catalysts of (a) precursors and (b) oxides after calcination at $800{ }^{\circ} \mathrm{C}$. (1) $\mathrm{MNC}_{0.8} \mathrm{~F}_{0.0}$; (2) $\mathrm{MNC}_{0.7} \mathrm{~F}_{0.1}$; (3) $\mathrm{MNC}_{0.5} \mathrm{~F}_{0.3}$; (4) $\mathrm{MNC}_{0.3} \mathrm{~F}_{0.5}$; and (5) $\mathrm{MNC}_{0.0} \mathrm{~F}_{0.8}$.

With Ca partly replaced by Fe in $\mathrm{MNC}_{0.7} \mathrm{~F}_{0.1}\left(\mathrm{MgNi}_{0.2} \mathrm{Ca}_{0.7} \mathrm{Fe}_{0.1} \mathrm{O}_{2 \pm \delta}\right)$, as shown in Figure $3 \mathrm{a}(2)$, the dolomite structure still remained as the main crystal phase, but calcite disappeared; meanwhile, there were peaks of hydrotalcite $\left(\mathrm{Ni}_{0.75} \mathrm{Fe}_{0.25}\left(\mathrm{CO}_{3}\right)_{0.125}(\mathrm{OH})_{2} .\left(\mathrm{H}_{2} \mathrm{O}\right)_{0.38}\right.$, JCPDS: 40-0215) and traces of magnesite $\left(\mathrm{MgCO}_{3}\right.$, JCPDS:08-0479).

With decreasing calcium and increasing iron in $\mathrm{MNC}_{0.5} \mathrm{~F}_{0.3}$ and $\mathrm{MNC}_{0.3} \mathrm{~F}_{0.5}$ (Figure $3 \mathrm{a}(3,4)$ ), peaks of dolomite and hydrotalcite became weaker. Meanwhile, similar iron-containing spinel phases ( $\mathrm{MgFe}_{2} \mathrm{O}_{4}$ (JCPDS: 73-2211), $\mathrm{Fe}_{3} \mathrm{O}_{4}$ (JCPDS: 75-0449), or $\mathrm{NiFe}_{2} \mathrm{O}_{4}$ (JCPDS: 74-2081)) [20] were observed and became stronger.

For the calcium-free catalyst of $\mathrm{MNC}_{0.0} \mathrm{~F}_{0.8}\left(\mathrm{MgNi}_{0.2} \mathrm{Fe}_{0.8} \mathrm{O}_{2 \pm \delta}\right)$ in Figure 3a(5), iron-containing spinel phases became the main crystal phases, while calcium-containing phases of dolomite, calcite and hydrotalcite disappeared.

\subsubsection{Oxides of Catalysts}

The precursors were then calcined at $800{ }^{\circ} \mathrm{C}$ and scanned by $\mathrm{XRD}$, as depicted in Figure $3 \mathrm{~b}$. For $\mathrm{MNC}_{0.8} \mathrm{~F}_{0.0}$ without iron (Figure $3 \mathrm{~b}(1)$ ), after calcination, the main phases of dolomite, brucite, and calcite were decomposed and transformed into lime (CaO, JCPDS: 74-1226) and periclase (MgO, JCPDS: 65-0476). For the nickel species, because of the similar crystal structure of $\mathrm{NiO}$ and $\mathrm{MgO}$, the nickel species probably existed in the solid solution as $\mathrm{Mg}(\mathrm{Ni}) \mathrm{O}$, for example, $\mathrm{Mg}_{0.6} \mathrm{Ni}_{0.4} \mathrm{O}$ (JCPDS: 65-2901) or $\mathrm{MgNiO}_{2}$ (JCPDS: 24-0712) [12,14].

With calcium partly replaced by iron in $\mathrm{MNC}_{0.7} \mathrm{~F}_{0.1}$ (Figure $3 \mathrm{~b}(2)$ ), in addition to the main phases of periclase and $\mathrm{CaO}$, traces of iron-containing spinel phase $\left(\mathrm{MgFe}_{2} \mathrm{O}_{4}, \mathrm{Fe}_{3} \mathrm{O}_{4}\right.$ or $\left.\mathrm{NiFe}_{2} \mathrm{O}_{4}\right)$ and brownmillerite-type species $\left(\mathrm{Ca}_{2} \mathrm{Fe}_{2} \mathrm{O}_{5}\right.$, JCPDS:71-2264) were found.

With more iron species in $\mathrm{MNC}_{0.5} \mathrm{~F}_{0.3}$ and $\mathrm{MNC}_{0.3} \mathrm{~F}_{0.5}$, the periclase phase of $\mathrm{Mg}(\mathrm{Ni}) \mathrm{O}$ was still the main phase, and peaks of $\mathrm{CaO}$ became weaker and almost disappeared. In contrast, iron-containing spinel phases became stronger, while $\mathrm{Ca}_{2} \mathrm{Fe}_{2} \mathrm{O}_{5}$ can still be tracked.

For the Ca-free catalyst of $\mathrm{MNC}_{0.0} \mathrm{~F}_{0.8}$, there were only two main phases of periclase and spinel $\left(\mathrm{MgFe}_{2} \mathrm{O}_{4}, \mathrm{Fe}_{3} \mathrm{O}_{4}\right.$, or $\left.\mathrm{NiFe}_{2} \mathrm{O}_{4}\right)$.

In order to understand texture properties in these catalysts, $\mathrm{N}_{2}$ physisorption was carried out, and the surface area $\left(\mathrm{S}_{\mathrm{BET}}\right)$ and pore distribution were analyzed, as shown in Table 1 . The $\mathrm{S}_{\mathrm{BET}}$ of the Fe-free catalyst of $\mathrm{MNC}_{0.8} \mathrm{~F}_{0.0}$ was recorded at $4.27 \mathrm{~m}^{2} / \mathrm{g}$; with Ca gradually replaced by $\mathrm{Fe}$, the $\mathrm{S}_{\mathrm{BET}}$ 
increased and reached $11.53 \mathrm{~m}^{2} / \mathrm{g}$ over $\mathrm{MNC}_{0.3} \mathrm{~F}_{0.5}$, suggesting that iron could be inserted into the periclase structures as $\mathrm{Mg}(\mathrm{Ni}, \mathrm{Fe}) \mathrm{O}$, resulting in higher surface area [14]. For the Ca-free catalyst of $\mathrm{MNC}_{0.0} \mathrm{~F}_{0.8}, \mathrm{~S}_{\mathrm{BET}}$ dropped to $4.7 \mathrm{~m}^{2} / \mathrm{g}$, which can be attributed to the dominant phase of spinel with low surface area, as shown in Figure $3 \mathrm{~b}$.

\subsubsection{Reduced Catalysts}

To find the state of active components before reaction, the catalysts were reduced at $650{ }^{\circ} \mathrm{C}$ for $1 \mathrm{~h}$ and then scanned by XRD, as shown in Figure 4a. For the iron-free catalyst of $\mathrm{MNC}_{0.8} \mathrm{~F}_{0.0}$, the two main phases of periclase and lime still remained, and no $\mathrm{Ni}^{0}$ species were detected, suggesting that the $\mathrm{Ni}$ species in periclase-like phase of $\mathrm{Mg}(\mathrm{Ni}) \mathrm{O}$ may either have not been reduced, or have been reduced into amorphous $\mathrm{Ni}^{0}$, and cannot be detected by XRD, which needs to be further checked by XPS later.

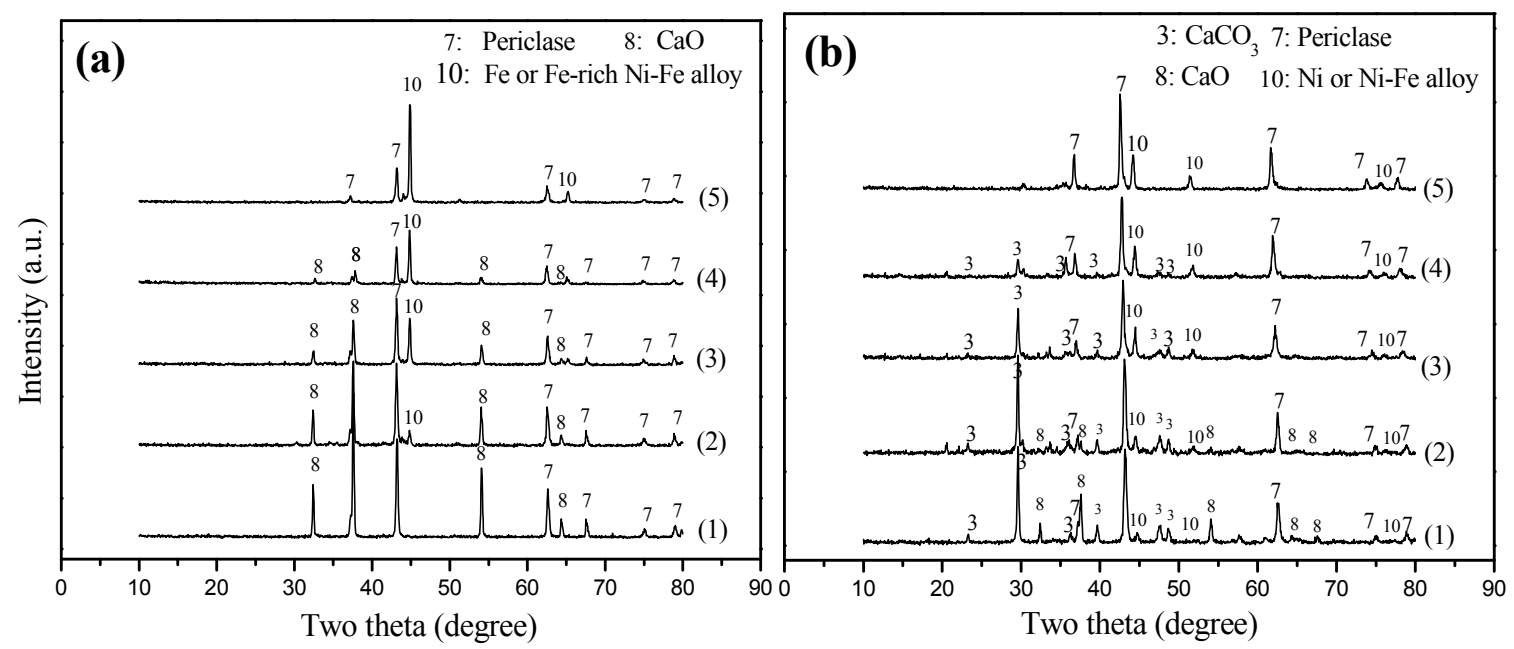

Figure 4. XRD patterns of Ni-based catalysts of (a) reduced at $650{ }^{\circ} \mathrm{C}$ and (b) spent after ATR. (1) $\mathrm{MNC}_{0.8} \mathrm{~F}_{0.0} ;$ (2) $\mathrm{MNC}_{0.7} \mathrm{~F}_{0.1}$; (3) $\mathrm{MNC}_{0.5} \mathrm{~F}_{0.3}$; (4) $\mathrm{MNC}_{0.3} \mathrm{~F}_{0.5}$; and (5) $\mathrm{MNC}_{0.0} \mathrm{~F}_{0.8}$.

With Ca gradually replaced by $\mathrm{Fe}$ in $\mathrm{MNC}_{0.7} \mathrm{~F}_{0.1}, \mathrm{MNC}_{0.5} \mathrm{~F}_{0.3}, \mathrm{MNC}_{0.3} \mathrm{Fe}_{0.5}$, and $\mathrm{MNC}_{0.0} \mathrm{~F}_{0.8}$, as shown in (Figure 4a), the iron-containing species of $\mathrm{Ca}_{2} \mathrm{Fe}_{2} \mathrm{O}_{5}$ and spinel phases $\left(\mathrm{MgFe}_{2} \mathrm{O}_{4}, \mathrm{Fe}_{3} \mathrm{O}_{4}\right.$ or $\mathrm{NiFe}_{2} \mathrm{O}_{4}$ ) disappeared after reduction at $650^{\circ} \mathrm{C}$. Accordingly, peaks of metallic $\alpha$-Fe (JCPDS: 03-1050) or similar Fe-rich Ni-Fe alloy (JCPDS: 03-1049) were observed and became stronger. Meanwhile, the peaks of periclase gradually shrank, suggesting that more Ni species and Fe species could also be reduced from the mixed solid solution of $\mathrm{Mg}(\mathrm{Ni}, \mathrm{Fe}) \mathrm{O}$.

For the Ca-free catalyst of $\mathrm{MNC}_{0.0} \mathrm{~F}_{0.8}$, the lime phase disappeared, and the periclase phase remained weaker, while the peaks of Fe or Ni-Fe alloy became the main phase.

XRD cannot identify $\mathrm{Ni}^{0}$ and $\mathrm{Fe}^{0}$ species in the amorphous state; however, XPS are more sensitive to the electronic state of $\mathrm{Ni}$ and $\mathrm{Fe}$ species. Therefore, XPS was conducted over the reduced catalysts of $\mathrm{MNC}_{0.8} \mathrm{~F}_{0.0}, \mathrm{MNC}_{0.5} \mathrm{~F}_{0.3}$ and $\mathrm{MNC}_{0.0} \mathrm{~F}_{0.8}$. As shown in Figure $5 \mathrm{a}-\mathrm{c}$ of $\mathrm{Ni} 2 \mathrm{p}_{3 / 2}$, there are peaks near binding energies at $852.1 \mathrm{eV}$ and $854.0 \mathrm{eV}$, which can be attributed to the characteristic peaks of $\mathrm{Ni}^{0}$ and $\mathrm{Ni}^{2+}$, respectively, while the peak near $861.0 \mathrm{eV}$ can be assigned to shake-up peak of $\mathrm{Ni}^{2+}$ species [21]. The semi-quantitative analysis was conducted via the peak areas: over these reduced catalysts, the molar ratio of $\mathrm{Ni}^{0} /\left(\mathrm{Ni}^{0}+\mathrm{Ni}^{2+}\right)$ was recorded near $9.0 \%$ in $\mathrm{MNC}_{0.8} \mathrm{~F}_{0.0}, 12.5 \%$ in $\mathrm{MNC}_{0.5} \mathrm{~F}_{0.3}$, and $14.1 \%$ in $\mathrm{MNC}_{0.0} \mathrm{~F}_{0.8}$, respectively, as shown in Table 3. The results indicate that the addition of Fe can promote to reduction of $\mathrm{Ni}$ species from the periclase phase of $\mathrm{Mg}(\mathrm{Ni}, \mathrm{Fe}) \mathrm{O}$, and is consistent with the shrank peaks of periclase in XRD (Figure 4a). 


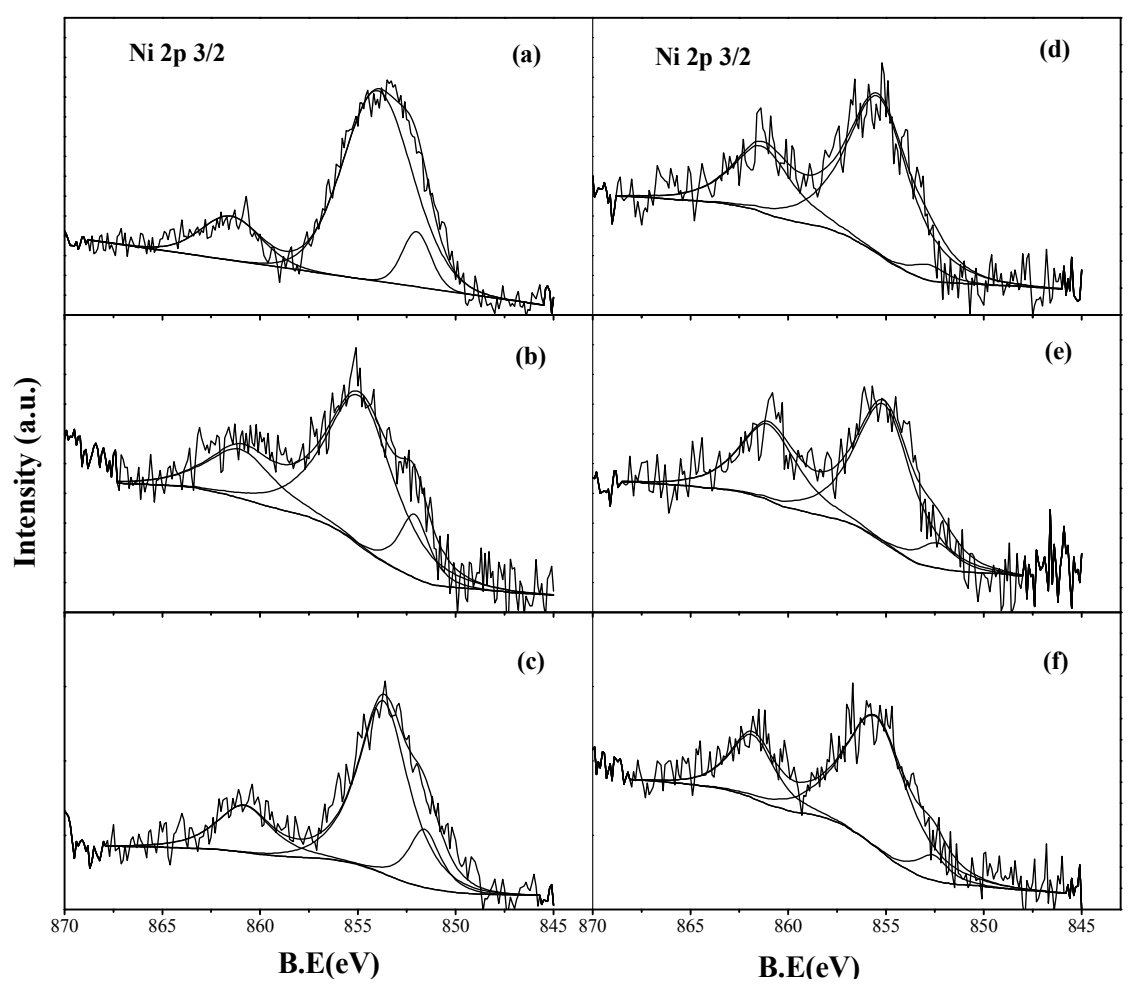

Figure 5. XPS of $\mathrm{Ni} 2 \mathrm{p}_{3 / 2}$ over the reduced catalysts (a) $\mathrm{MNC}_{0.8} \mathrm{~F}_{0.0} ;$ (b) $\mathrm{MNC}_{0.5} \mathrm{~F}_{0.3}$ and (c) $\mathrm{MNC}_{0.0} \mathrm{~F}_{0.8}$; and spent catalysts of (d) $\mathrm{MNC}_{0.8} \mathrm{~F}_{0.0} ;(\mathbf{e}) \mathrm{MNC}_{0.5} \mathrm{~F}_{0.3} ;$ and (f) $\mathrm{MNC}_{0.0} \mathrm{~F}_{0.8}$.

Table 3. The molar percentages of surface Ni/Fe species over the Ni-based catalysts from XPS.

\begin{tabular}{|c|c|c|c|c|c|c|}
\hline \multirow{2}{*}{ Species } & \multicolumn{2}{|c|}{$\mathrm{MNC}_{0.8} \mathrm{~F}_{0.0}$} & \multicolumn{2}{|c|}{$\mathrm{MNC}_{0.5} \mathrm{~F}_{0.3}$} & \multicolumn{2}{|c|}{$\mathrm{MNC}_{0.0} \mathrm{~F}_{0.8}$} \\
\hline & Reduced & Spent & Reduced & Spent & Reduced & Spent \\
\hline $\mathrm{Ni}^{0} /\left(\mathrm{Ni}^{0 \mathrm{v}}+\mathrm{Ni}^{2+}\right) / \%$ & 9.0 & 3.7 & 12.5 & 8.8 & 14.1 & 6.7 \\
\hline $\mathrm{Fe}^{0} /\left(\mathrm{Fe}^{0}+\mathrm{Fe}^{2+}+\mathrm{Fe}^{3+}\right) / \%$ & N.A. & N.A. & 70.9 & 12.9 & 77.6 & 4.6 \\
\hline
\end{tabular}

For the Fe species in reduced catalysts, as shown in Figure 6, the spectra of $\mathrm{Fe} 2 \mathrm{p}_{3 / 2}$ can be deconvoluted into six peaks; among these peaks, the peak near $706.8 \mathrm{eV}$ can be assigned to $\mathrm{Fe}^{0}$, while other peaks near $709.8 \mathrm{eV}, 710.8 \mathrm{eV}, 711.6 \mathrm{eV}, 712.6 \mathrm{eV}$, and $713.7 \mathrm{eV}$ can be assigned to oxides of $\mathrm{Fe}^{2+} / \mathrm{Fe}^{3+}$ [22-24]. Over the reduced catalysts of $\mathrm{MNC}_{0.5} \mathrm{~F}_{0.3}$ and $\mathrm{MNC}_{0.0} \mathrm{~F}_{0.8}$ in Figure $6 \mathrm{a}, \mathrm{b}$ and Table 3, there are strong peaks of $\mathrm{Fe}^{0}$ with a molar ratio of $\mathrm{Fe}^{0} /\left(\mathrm{Fe}^{0}+\mathrm{Fe}^{2+}+\mathrm{Fe}^{3+}\right)$ near $70.9 \%$ and $77.6 \%$, respectively, which is consistent with the strong peaks of Fe or Fe-rich Ni-Fe alloy in XRD (Figure 4a).

The reducible properties were also tested by temperature-programmed reduction (TPR). As shown in Figure 7, over the iron-free catalyst of $\mathrm{MNC}_{0.8} \mathrm{~F}_{0.0}$ (Figure $7(1)$ ), there are two weak reduction peaks: one weak peak starts from $343{ }^{\circ} \mathrm{C}$ to $650{ }^{\circ} \mathrm{C}$ and centers at $619{ }^{\circ} \mathrm{C}$, which can be attributed to the reduction of surface or amorphous $\mathrm{NiO}$ species; the other high-temperature peak centered at $992{ }^{\circ} \mathrm{C}$ can be attributed to the reduction of nickel species in periclase of $\mathrm{Mg}(\mathrm{Ni}) \mathrm{O}$ [25], according to the result of XRD. These two weak reduction peaks suggest that only traces of $\mathrm{Ni}$ species were reduced below $650{ }^{\circ} \mathrm{C}$, and is consistent with the result of XPS with only $9.0 \%$ of Ni species reduced.

With addition of iron in $\mathrm{MNC}_{0.7} \mathrm{~F}_{0.1}$, one more reduction peak emerges near $836^{\circ} \mathrm{C}$, which can be mainly attributed to the phase of $\mathrm{Ca}_{2} \mathrm{Fe}_{2} \mathrm{O}_{5}$, accordingly results of XRD (Figure $3 \mathrm{~b}(2)$ ). With more Fe and less $\mathrm{Ca}$ in $\mathrm{MNC}_{0.5} \mathrm{~F}_{0.3}$ and $\mathrm{MNC}_{0.3} \mathrm{~F}_{0.5}$, the phase of $\mathrm{Ca}_{2} \mathrm{Fe}_{2} \mathrm{O}_{5}$ was weakened, as indicated by XRD (Figure $3 b(3,4)$ ), and the reduction peaks near $836{ }^{\circ} \mathrm{C}$ shrank; meanwhile, spinel phases $\left(\mathrm{MgFe}_{2} \mathrm{O}_{4}, \mathrm{NiFe}_{2} \mathrm{O}_{4}\right.$ or $\left.\mathrm{Fe}_{3} \mathrm{O}_{4}\right)$ intensified, thus the reduction peaks near $600{ }^{\circ} \mathrm{C}$ and $890{ }^{\circ} \mathrm{C}$ intensified 
accordingly. Over the Ca-free catalyst of $\mathrm{MNC}_{0.0} \mathrm{~F}_{0.8}$, strong reduction peaks of Fe-containing spinel phases dominated the TPR profile, according to XRD file of Figure $3 b(5)$.

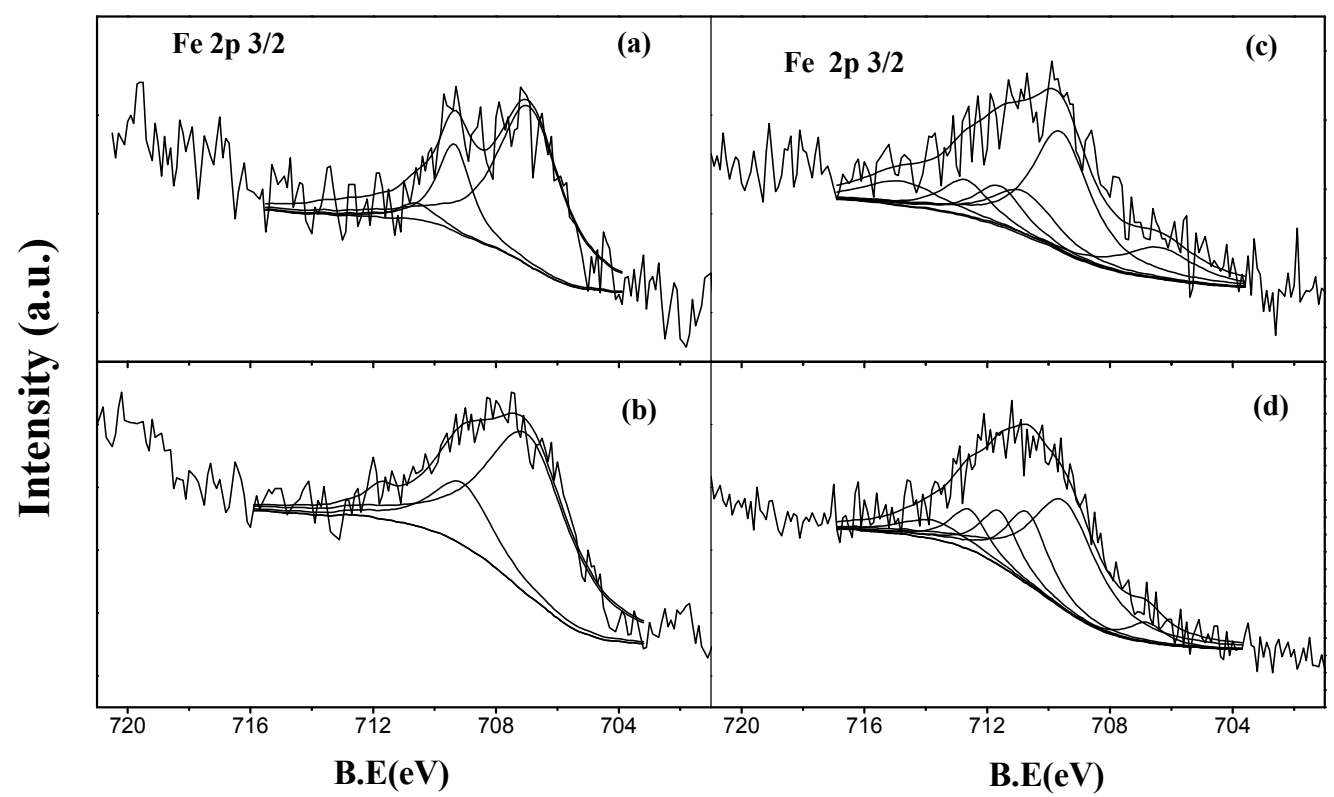

Figure 6. XPS of Fe $2 \mathrm{p}_{3 / 2}$ in the reduced catalysts of (a) $\mathrm{MNC}_{0.5} \mathrm{~F}_{0.3}$ and (b) $\mathrm{MNC}_{0.0} \mathrm{~F}_{0.8}$, and spent catalysts of (c) $\mathrm{MNC}_{0.5} \mathrm{~F}_{0.3}$ and (d) $\mathrm{MNC}_{0.0} \mathrm{~F}_{0.8}$.

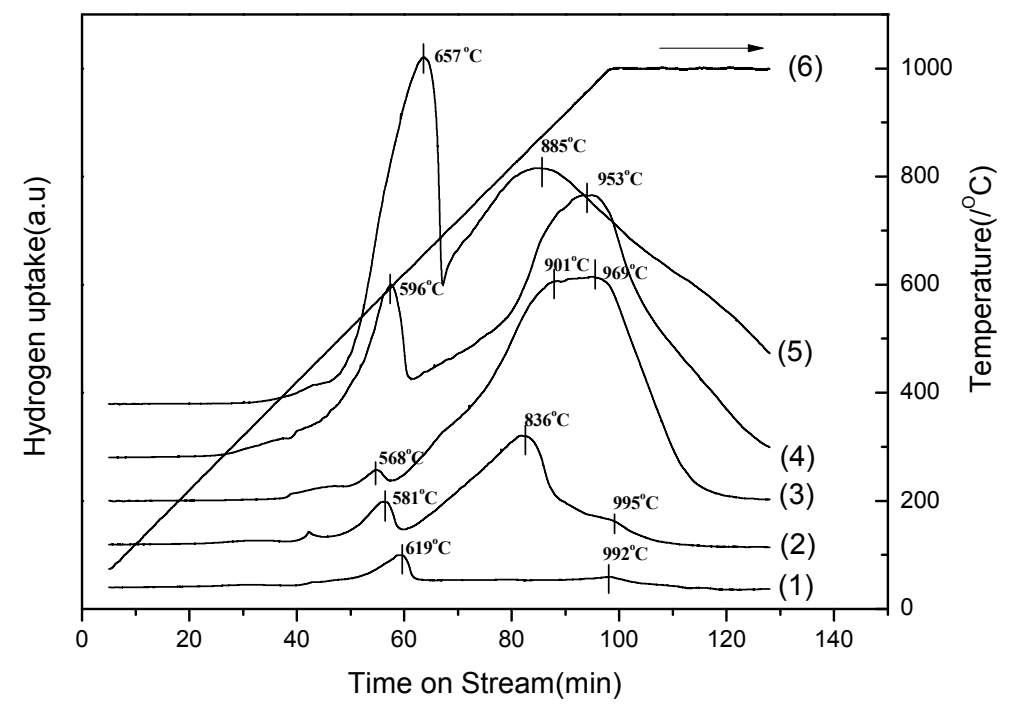

Figure 7. Profiles of temperature-programmed reduction of $\mathrm{MNCF}$ catalysts: (1) $\mathrm{MNC}_{0.8} \mathrm{~F}_{0.0}$; (2) $\mathrm{MNC}_{0.7} \mathrm{~F}_{0.1} ;(3) \mathrm{MNC}_{0.5} \mathrm{~F}_{0.3} ;(4) \mathrm{MNC}_{0.3} \mathrm{~F}_{0.5}$; and (5) $\mathrm{MNC}_{0.0} \mathrm{~F}_{0.8} ;(6)$ temperature.

\subsubsection{Spent Catalysts}

To find the crystal variation after the ATR test, the spent catalysts were scanned by XRD. As shown in Figure $4 \mathrm{~b}$, the periclase phase still remained in the iron-free catalyst of $\mathrm{MNC}_{0.8} \mathrm{~F}_{0.0}$, but the peaks of $\mathrm{CaO}$ shrunk remarkably with emergence of peaks of $\mathrm{CaCO}_{3}$, suggesting that $\mathrm{CaO}$ was mainly transformed into $\mathrm{CaCO}_{3}$ with $\mathrm{CO}_{2}$ produced in the ATR process. With introduction of iron and decreasing content of $\mathrm{Ca}$ in $\mathrm{MNC}_{0.7} \mathrm{~F}_{0.1}, \mathrm{MNC}_{0.5} \mathrm{~F}_{0.3}$, and $\mathrm{MNC}_{0.3} \mathrm{~F}_{0.5}$, the $\mathrm{CaCO}_{3}$ and $\mathrm{CaO}$ phases were fading continuously and disappeared eventually; meanwhile, the peaks of periclase, which were weakening in the reduced catalysts, were intensifying in these spent catalysts. In the meantime, the 
strong peaks of $\mathrm{Fe}$ or Ni-Fe alloy near $44.5^{\circ}$ became weak, suggesting that the $\mathrm{Fe}^{0}$ species could have been partly oxidized during ATR.

To verify the Fe and Ni species after ATR test, the spent catalysts were scanned by XPS. As shown in Figure $6 \mathrm{c}, \mathrm{d}$, after the ATR test, the peak of $\mathrm{Fe}^{0}$ in $\mathrm{MNC}_{0.5} \mathrm{Fe}_{0.3}$ and $\mathrm{MNC}_{0.0} \mathrm{~F}_{0.8}$ shrank remarkably with a molar ratio of $\mathrm{Fe}^{0} /\left(\mathrm{Fe}^{0}+\mathrm{Fe}^{2+}+\mathrm{Fe}^{3+}\right)$ near $12.9 \%$ and $4.6 \%$, respectively, indicating that the $\mathrm{Fe}$ metal species did be oxidized and could form in the intensified phases of periclase as $\mathrm{Mg}(\mathrm{Ni}, \mathrm{Fe}) \mathrm{O}$, as shown in XRD of Figure $4 \mathrm{~b}$.

For the $\mathrm{Ni}$ species in the spent catalysts, as shown in Figure $5 \mathrm{~d}, \mathrm{f}$, the peak of $\mathrm{Ni}^{0}$ also became slightly weakened, and the ratio of $\mathrm{Ni}^{0} /\left(\mathrm{Ni}^{0}+\mathrm{Ni}^{2+}\right)$ over the spent catalysts of $\mathrm{MNC}_{0.8} \mathrm{~F}_{0.0}$, $\mathrm{MNC}_{0.5} \mathrm{Fe}_{0.3}$, and $\mathrm{MNC}_{0.0} \mathrm{~F}_{0.8}$ were $3.7 \%, 8.8 \%$, and $6.7 \%$, respectively, suggesting that the additive of iron was helpful to resist the oxidation of $\mathrm{Ni}^{0}$ during ATR.

Thermogravimetry (TG) was conducted as well, and minor weight loss (less than $1.8 \%$ ) was recorded in these catalysts, while no carbon species were found in the spent catalysts in XRD of Figure $4 \mathrm{~b}$, suggesting that coking has been constrained in these Ni-based catalysts with basic support of $\mathrm{MgO} / \mathrm{CaO}$ during ATR test.

\section{Discussion}

Based on the characterization results, one can find that the dolomite structure can be formed via hydrothermal synthesis with Pluronic P123. For the $\mathrm{MNC}_{0.8} \mathrm{Fe}_{0.0}$ catalyst without $\mathrm{Fe}$ $\left(\mathrm{MgNi}_{0.2} \mathrm{Ca}_{0.8} \mathrm{O}_{2 \pm \delta}\right)$, dolomite was the main phase with trace of hydroxide of magnesium and nickel. After calcination, the dolomite precursors were transformed into periclase of solid solution as $\mathrm{Mg}(\mathrm{Ni}) \mathrm{O}$ and $\mathrm{CaO}$. The $\mathrm{MNC}_{0.8} \mathrm{Fe}_{0.0}$ catalyst produced an $\mathrm{AC}$ conversion near $97.2 \%$ with a $\mathrm{H}_{2}$ yield near $2.1 \mathrm{~mol}-\mathrm{H}_{2} / \mathrm{mol}-\mathrm{AC}$, because about $10.4 \%$ of AC was transformed into acetone.

With Ca partly replaced by $\mathrm{Fe}$, dolomite still remained the main phase, while Fe-containing phases of hydrotalcite and spinel $\left(\mathrm{MgFe}_{2} \mathrm{O}_{4}, \mathrm{Fe}_{3} \mathrm{O}_{4}\right.$, or $\left.\mathrm{NiFe}_{2} \mathrm{O}_{4}\right)$ were found in the precursor of $\mathrm{MNC}_{0.5} \mathrm{Fe}_{0.3}\left(\mathrm{MgNi}_{0.2} \mathrm{Ca}_{0.5} \mathrm{Fe}_{0.3} \mathrm{O}_{2 \pm \delta}\right)$. After calcination, these phases were transformed into a main phase of periclase as $\mathrm{Mg}(\mathrm{Ni}, \mathrm{Fe}) \mathrm{O}$ with high surface area and minor phases of $\mathrm{Ca}_{2} \mathrm{Fe}_{2} \mathrm{O}_{5}$ and spinel. After reduction at $650{ }^{\circ} \mathrm{C}$, main part of iron oxides (up to $70.9 \%$ ) were reduced and formed in Fe-rich $\mathrm{Ni}-\mathrm{Fe}$ alloy, or $\alpha$-Fe metals, as shown in XRD (Figure 4a) and XPS (Figure 6). As a result, because of the synergetic effect of $\mathrm{Fe}$ and $\mathrm{Ni}$ with basic support of $\mathrm{CaO}-\mathrm{MgO}$ in ATR $[14,26]$, the AC in the feed completely converted, and the $\mathrm{H}_{2}$ yield reached 2.6 mol- $\mathrm{H}_{2} /$ mol-AC and remained stable, while $\mathrm{Ni}$ species remained relatively stable with Fe promotion during ATR, as shown by XPS and XPD.

For $\mathrm{MNC}_{0.0} \mathrm{Fe}_{0.8}\left(\mathrm{MgNi}_{0.2} \mathrm{Fe}_{0.8} \mathrm{O}_{2 \pm \delta}\right)$ with $\mathrm{Ca}$ completely replaced by $\mathrm{Fe}$, there were only Fe-containing spinel phases and weak magnesite phases formed; after calcination, the spinel phases with low surface area became the main phase. After reduction, strong peaks of $\alpha$-Fe or Fe-rich $\mathrm{Ni}-\mathrm{Fe}$ alloy were found from spinel phases; during the ATR test, although the conversion of AC was stable near $100 \%$, the $\mathrm{H}_{2}$ yield decreased to 2.1 mol- $\mathrm{H}_{2} /$ mol-AC, which can be attributed to part oxidization of $\mathrm{Fe}^{\circ}$ as well as $\mathrm{Ni}^{0}$ in Ni-Fe alloy, as shown in spent catalysts of XRD (Figure $4 \mathrm{~b}$ ) and XPS (Figures 5 and 6).

\section{Materials and Methods}

\subsection{Catalyst Preparation}

Ni-based dolomite-derived catalysts were prepared via hydrothermal synthesis. Firstly, an aqueous solution of $\mathrm{Ni}\left(\mathrm{NO}_{3}\right)_{2} \cdot 6 \mathrm{H}_{2} \mathrm{O}, \mathrm{Ca}\left(\mathrm{NO}_{3}\right)_{2} \cdot 4 \mathrm{H}_{2} \mathrm{O}, \mathrm{Mg}\left(\mathrm{NO}_{3}\right)_{2} \cdot 6 \mathrm{H}_{2} \mathrm{O}$, and $\mathrm{Fe}\left(\mathrm{NO}_{3}\right)_{3} \cdot 9 \mathrm{H}_{2} \mathrm{O}$ was prepared, and precipitated by $\mathrm{Na}_{2} \mathrm{CO}_{3}$ with (total of metal cation electron charge) $/\left(\mathrm{CO}_{3}{ }^{2-}\right)=4$ at $\mathrm{pH}=10.5 \pm 0.5$ under vigorous stirring, while $\mathrm{NaOH}$ was added as a $\mathrm{pH}$ adjuster. (The reagents mentioned in this sentence were purchased from Keshi Chemicals, Chengdu, Sichuan, China). After the precipitation process, a tri-block copolymer of (EO)20(PO)70(EO)20 (Pluronic P123, typical $M n=5800$, Sigma-Aldrich, St. Louis, MO, USA) with a molar ratio of Ni/P123 $=40$ was added into the suspension. 
The mixture was continuously stirred for $2 \mathrm{~h}$ at room temperature, transferred to an autoclave and remained at $150{ }^{\circ} \mathrm{C}$ for $36 \mathrm{~h}$. The obtained precipitate was filtered and washed three times with distilled water, dried at $105{ }^{\circ} \mathrm{C}$ for $24 \mathrm{~h}$, and calcined at $800^{\circ} \mathrm{C}$ for $4 \mathrm{~h}$ in air. These Ni-based catalysts are listed in Table 1, while the weight compositions were checked by ICP-AES and are close to the nominal compositions.

\subsection{Catalytic Performance Test}

ATR of acetic acid (AC) was conducted in a continuous-flow fixed-bed quartz-tubing reactor (I.D. $6 \mathrm{~mm}$ ). $500 \mathrm{mg}$ of catalyst (grain size of $20-40 \mathrm{mesh}$ ) was sandwiched between quartz wool in the reactor, and reduced in $\mathrm{H}_{2}$ at $650{ }^{\circ} \mathrm{C}$ for $1 \mathrm{~h}$ before reaction. The mixture of water and $\mathrm{AC}$ (Keshi Chemicals, Chengdu, Sichuan, China) was then vaporized at $330^{\circ} \mathrm{C}$ by a pre-heater, mixed with an $\mathrm{O}_{2} / \mathrm{N}_{2}$ gas, $\mathrm{N}_{2}$ gas (Dongfeng Gas, Chengdu, Sichuan, China), and fed into the reactor with a molar ratio of $\mathrm{CH}_{3} \mathrm{COOH}: \mathrm{H}_{2} \mathrm{O}: \mathrm{O}_{2}: \mathrm{N}_{2}=1: 8: 0.28: 3.92$ at $3.6 \mathrm{~g}-\mathrm{AC} /\left(\mathrm{g}\right.$-catalyst.h), $650{ }^{\circ} \mathrm{C}$ and $1 \mathrm{~atm}$. The tail gas was analyzed online by a gas chromatography (GC-7890, Lunan Ruihong Instrument, Tengzhou, Shangdong, China) with TCD detectors via columns of carbon molecular sieves and Porapark $Q$ (Sepulco Inc., Bellefonte, PA, USA), while $\mathrm{N}_{2}$ was used as internal standard for analysis.

AC conversion $\left(\mathrm{X}_{\mathrm{AC}}\right)$, selectivity of carbon-containing products $\left(\mathrm{S}_{\mathrm{i}}\right)$, and hydrogen yield $\left(\mathrm{Y}_{\mathrm{H} 2}\right)$, were calculated according to the following equations:

$$
\begin{aligned}
& X_{A C}(\%)=\frac{F_{A C \text { in }}-F_{A C} \text { out }}{F_{A C \text { in }}} \cdot 100 \\
& S_{i \text { carbon-containing product }}(\%)=\frac{F_{i \text { carbon-containing product }}}{n i\left(F_{A C} \text { in }-F_{A C} \text { out }\right)} \cdot 100 \\
& Y_{H 2}=\frac{F_{H 2} \text { product }}{F_{A C \text { in }}}
\end{aligned}
$$

In the above equations, $F_{i}$ in or out is the molar flow rate of the $i$ species at the inlet or the outlet of the reactor, and $n_{i}$ is the stoichiometric factor between the carbon-containing products and acetic acid.

\subsection{Catalyst Characterization}

The composition of catalysts was measured by elemental analysis with an inductively coupled plasma-atomic emission spectrometer (ICP-AES) (IRIS1000, Thermo Electron, Waltham, MA, USA).

The X-ray diffraction (XRD) patterns were recorded on an X-ray diffractometer (DX-2700, Haoyuan Instrument, Dandong, Liaoning, China) equipped with a graphite monochromator for $\mathrm{Cu} K \alpha$ radiation.

Temperature-programmed reduction (TPR) was performed in a downstream fixed-bed quartz-tubing reactor at $10{ }^{\circ} \mathrm{C} / \mathrm{min}$ in a flow of $5.0 \% \mathrm{H}_{2} / \mathrm{N}_{2}$ by an adsorption instrument (TP-5076, Xianquan Instrument, Tianjin, China).

Specific surface areas and pore size of calcined samples were analyzed at $-196{ }^{\circ} \mathrm{C}$ by $\mathrm{N}_{2}$ physisorption on an automatic adsorption instrument (JW-BK112, JWGB, Beijing, China).

X-ray photoelectron spectroscopy (XPS) was recorded by a Kratos Axis-Ultra DLD spectrometer (Kratos Inc., Manchester, UK) using Al K $\alpha$ radiation $(1486.6 \mathrm{eV})$. The binding energies were calibrated relative to the $C_{1 s}$ peak from the carbon contamination at $284.6 \mathrm{eV}$.

Thermogravimetric analysis (TG) was conducted in air with a STA 409 PC/PG analyzer (NESZSCH, Selb, Germany) at a heating rate of $10^{\circ} \mathrm{C} / \mathrm{min}$.

\section{Conclusions}

Dolomite-derived Ni-based catalysts with Fe additive, $\mathrm{MgNi}_{0.2} \mathrm{Ca}_{0.8}{ }_{-x} \mathrm{Fe}_{x} \mathrm{O}_{2 \pm \delta}(x=0-0.8)$, were successfully synthesized via the hydrothermal synthesis method. From the dolomite precursors, phases of $\mathrm{CaO}$ and periclase-like solid solution of $\mathrm{Mg}(\mathrm{Ni}, \mathrm{Fe}) \mathrm{O}$ with high surface area were formed with calcination. After reduction, there are more $\mathrm{Ni}$ species transformed into $\mathrm{Ni}^{0}$ as $\mathrm{Ni}-\mathrm{Fe}$ alloy, and these $\mathrm{Ni}^{0}$ remained relatively stable during the oxidative atmosphere of ATR, as suggested by XRD and XPS, while the $\mathrm{Fe}^{0}$ species were partly oxidized and formed in $\mathrm{Mg}(\mathrm{Ni}, \mathrm{Fe}) \mathrm{O}$. Meanwhile, because 
of the basic support of $\mathrm{CaO}-\mathrm{MgO}$ in the catalysts derived from the dolomite structure, coking has been constrained during the ATR test. As a result, the $\mathrm{MgNi}_{0.2} \mathrm{Ca}_{0.5} \mathrm{Fe}_{0.3} \mathrm{O}_{2 \pm \delta}$ catalyst performed a stable reactivity in ATR: the conversion of AC reached $100 \%$, and the $\mathrm{H}_{2}$ yield remained stable around $2.6 \mathrm{~mol}-\mathrm{H}_{2} / \mathrm{mol}-\mathrm{AC}$.

Acknowledgments: This work was financially supported by National Natural Science Foundation of China (NSFC: 21276031), and International Cooperation program sponsored by Science \& Technology Department of Sichuan Province of China (2015HH0013).

Author Contributions: The experimental work was designed by L.H. and X.Z.; X.Z, N.W., W.X., Y.D., and R.S. performed the experiments; X.Z., N.W. and L.H. analyzed the data; W.X. and N.W. contributed reagents/materials/analysis tools; X.Z., R.S. and L.H. drafted the paper. The manuscript was amended through the comments of all authors. All authors have given approval for the final version of the manuscript.

Conflicts of Interest: The authors declare no conflict of interest.

\section{References}

1. Trane, R.; Dahl, S.; Skjøth-Rasmussen, M.S.; Jensen, A.D. Catalytic steam reforming of bio-oil. Int. J. Hydrog. Energy 2012, 37, 6447-6472. [CrossRef]

2. Ayalur Chattanathan, S.; Adhikari, S.; Abdoulmoumine, N. A review on current status of hydrogen production from bio-oil. Renew. Sustain. Energy Rev. 2012, 16, 2366-2372. [CrossRef]

3. Chen, T.; Wu, C.; Liu, R. Steam reforming of bio-oil from rice husks fast pyrolysis for hydrogen production. Bioresour. Technol. 2011, 102, 9236-9240. [CrossRef] [PubMed]

4. Li, Z.; Hu, X.; Zhang, L.; Liu, S.; Lu, G. Steam reforming of acetic acid over $\mathrm{Ni} / \mathrm{ZrO}_{2}$ catalysts: Effects of nickel loading and particle size on product distribution and coke formation. Appl. Catal. A-Gen. 2012, 417-418, 281-289. [CrossRef]

5. Mohanty, P.; Patel, M.; Pant, K.K. Hydrogen production from steam reforming of acetic acid over Cu-Zn supported calcium aluminate. Bioresour. Technol. 2012, 123, 558-565. [CrossRef] [PubMed]

6. Konsolakis, M.; Ioakimidis, Z.; Kraia, T.; Marnellos, G. Hydrogen Production by Ethanol Steam Reforming (ESR) over $\mathrm{CeO} 2$ Supported Transition Metal ( $\mathrm{Fe}, \mathrm{Co}, \mathrm{Ni}, \mathrm{Cu}$ ) Catalysts: Insight into the Structure-Activity Relationship. Catalysts 2016, 6. [CrossRef]

7. Feng, M.S.; Liu, J.D.; Zhang, F.B.; Huang, L.H. Ni-based olivine-type catalysts and their application in hydrogen production via auto-thermal reforming of acetic acid. Chem. Pap. 2015, 69, 1166-1175. [CrossRef]

8. Seyedeyn Azad, F.; Abedi, J.; Salehi, E.; Harding, T. Production of hydrogen via steam reforming of bio-oil over Ni-based catalysts: Effect of support. Chem. Eng. J. 2012, 180, 145-150. [CrossRef]

9. Jang, W.-J.; Jeong, D.-W.; Shim, J.-O.; Kim, H.-M.; Han, W.-B.; Bae, J.W.; Roh, H.-S. Metal oxide (MgO, CaO, and $\mathrm{La} 2 \mathrm{O} 3)$ promoted $\mathrm{Ni}-\mathrm{Ce} 0.8 \mathrm{Zr} 0.2 \mathrm{O} 2$ catalysts for $\mathrm{H} 2$ and $\mathrm{CO}$ production from two major greenhouse gases. Renew. Energy 2015, 79, 91-95. [CrossRef]

10. Nichele, V.; Signoretto, M.; Pinna, F.; Menegazzo, F.; Rossetti, I.; Cruciani, G.; Cerrato, G.; Di Michele, A. $\mathrm{Ni} / \mathrm{ZrO}_{2}$ catalysts in ethanol steam reforming: Inhibition of coke formation by CaO-doping. Appl. Catal. B Environ. 2014, 150-151, 12-20. [CrossRef]

11. Alipour, Z.; Rezaei, M.; Meshkani, F. Effects of support modifiers on the catalytic performance of Ni/ $\mathrm{Al}_{2} \mathrm{O}_{3}$ catalyst in $\mathrm{CO}_{2}$ reforming of methane. Fuel 2014, 129, 197-203. [CrossRef]

12. Huang, L.H.; Liu, Q.; Chen, R.R.; Hsu, A.T. Hydrogen production via auto-thermal reforming of bio-ethanol: The role of iron in layered double hydroxide-derived $\mathrm{Ni}_{0.35} \mathrm{Mg}_{2.65} \mathrm{AlO}_{4.5+/ \delta}$ catalysts. Appl. Catal. A Gen. 2011, 393, 302-308. [CrossRef]

13. Pighini, C.; Belin, T.; Mijoin, J.; Magnoux, P.; Costentin, G.; Lauron-Pernot, H. Microcalorimetric and thermodynamic studies of $\mathrm{CO}_{2}$ and methanol adsorption on magnesium oxide. Appl. Surf. Sci. 2011, 257, 6952-6962. [CrossRef]

14. Djaidja, A.; Messaoudi, H.; Kaddeche, D.; Barama, A. Study of Ni-M/MgO and Ni-M-Mg/Al (M=Fe or $\mathrm{Cu})$ catalysts in the $\mathrm{CH}_{4}-\mathrm{CO}_{2}$ and $\mathrm{CH}_{4}-\mathrm{H}_{2} \mathrm{O}$ reforming. Int. J. Hydrog. Energy 2015, 40, 4989-4995. [CrossRef]

15. Hu, P.; Long, M. Cobalt-catalyzed sulfate radical-based advanced oxidation: A review on heterogeneous catalysts and applications. Appl. Catal. B Environ. 2016, 181, 103-117. [CrossRef]

16. Shang, R.; Duan, Y.; Zhong, X.; Xie, W.; Luo, Y.; Huang, L. Formic Acid Modified $\mathrm{Co}_{3} \mathrm{O}_{4}-\mathrm{CeO}_{2}$ Catalysts for CO Oxidation. Catalysts 2016, 6. [CrossRef] 
17. Mekhemer, G.A.H.; Halawy, S.A.; Mohamed, M.A.; Zaki, M.I. Ketonization of acetic acid vapour over polycrystalline magnesia: in situ Fourier transform infrared spectroscopy and kinetic studies. J. Catal. 2005, 230, 109-122. [CrossRef]

18. Guil-Lopez, R.; Navarro, R.M.; Ismail, A.A.; Al-Sayari, S.A.; Fierro, J.L.G. Influence of Ni environment on the reactivity of $\mathrm{Ni}-\mathrm{Mg}-\mathrm{Al}$ catalysts for the acetone steam reforming reaction. Int. J. Hydrog. Energy 2015, 40, 5289-5296. [CrossRef]

19. Zhang, F.B.; Wang, N.; Yang, L.; Li, M.; Huang, L.H. Ni-Co bimetallic MgO-based catalysts for hydrogen production via steam reforming of acetic acid from bio-oil. Int. J. Hydrog. Energy 2014, 39, 18688-18694. [CrossRef]

20. Adhlakha, N.; Yadav, K.L. Structural, dielectric, magnetic, and optical properties of $\mathrm{Ni}_{0.75} \mathrm{Zn}_{0.25} \mathrm{Fe}_{2} \mathrm{O}_{4}-\mathrm{BiFeO}_{3}$ composites. J. Mater. Sci. 2014, 49, 4423-4438. [CrossRef]

21. Pintea, S.; Rednic, V.; Mărginean, P.; Aldea, N.; Tiandou, H.; Wu, Z.; Neumann, M.; Matei, F. Crystalline and electronic structure of $\mathrm{Ni}$ nanoclusters supported on $\mathrm{Al}_{2} \mathrm{O}_{3}$ and $\mathrm{Cr}_{2} \mathrm{O}_{3}$ investigated by XRD, XAS and XPS methods. Superlattice Microst. 2009, 46, 130-136. [CrossRef]

22. Biesinger, M.C.; Payne, B.P.; Grosvenor, A.P.; Lau, L.W.M.; Gerson, A.R.; Smart, R.S.C. Resolving surface chemical states in XPS analysis of first row transition metals, oxides and hydroxides: $\mathrm{Cr}, \mathrm{Mn}, \mathrm{Fe}, \mathrm{Co}$ and $\mathrm{Ni}$. Appl. Surf. Sci. 2011, 257, 2717-2730. [CrossRef]

23. Reddy, G.K.; Boolchand, P.; Smirniotis, P.G. Sulfur tolerant metal doped Fe/Ce catalysts for high temperature WGS reaction at low steam to CO ratios-XPS and Mössbauer spectroscopic study. J. Catal. 2011, 282, 258-269. [CrossRef]

24. Brajpuriya, R.; Shripathi, T. Investigation of Fe/Al interface as a function of annealing temperature using XPS. Appl. Surf. Sci. 2009, 255, 6149-6154. [CrossRef]

25. Lin, X.; Li, R.; Lu, M.; Chen, C.; Li, D.; Zhan, Y.; Jiang, L. Carbon dioxide reforming of methane over Ni catalysts prepared from Ni-Mg-Al layered double hydroxides: Influence of Ni loadings. Fuel 2015, 162, 271-280. [CrossRef]

26. Ren, J.; Qin, X.; Yang, J.-Z.; Qin, Z.-F.; Guo, H.-L.; Lin, J.-Y.; Li, Z. Methanation of carbon dioxide over $\mathrm{Ni}-\mathrm{M} / \mathrm{ZrO}_{2}(\mathrm{M}=\mathrm{Fe}, \mathrm{Co}, \mathrm{Cu})$ catalysts: Effect of addition of a second metal. Fuel Process. Technol. 2015, 137, 204-211. [CrossRef]

(C) 2016 by the authors; licensee MDPI, Basel, Switzerland. This article is an open access article distributed under the terms and conditions of the Creative Commons Attribution (CC-BY) license (http:/ / creativecommons.org/licenses/by/4.0/). 